\title{
ANALITICAL AND ARTIFICIAL NEURAL NETWORK MODELS OF DISCHARGE VALUE PASSING OVER OGEE SPILLWAY
}

\author{
1Alpaslan YARAR \\ ${ }^{1}$ Selcuk University, Engineering Faculty, Civil Engineering Department Hydraulics Division, \\ 42031 Konya, Turkey \\ 1ayarar@selcuk.edu.tr
}

(Geliş/Received: 10.02.2017; Kabul/Accepted in Revised Form: 28.03.2017)

\begin{abstract}
In this study, analytical and Artificial Neural Network (ANN) models' output of the discharge value, passing over Ogee Spillways, were compared. For this aim, a flume having $7.5 \mathrm{~cm}$ width, $15 \mathrm{~cm}$ depth and $5 \mathrm{~m}$ length, was used in the laboratory. Discharge values above the spillway were measured for different heads. Discharge values were also computed by the formula for the measured heads. An ANN model was set by using the experimental results in order to estimate the discharge value. So, the performance of the ANN model was investigated. As the result, it was seen that ANN model produced very successful output.
\end{abstract}

Key Words: Discharge, Ogee spillway, Artificial neural networks

Ogee Tipi Dolusavakların Üzerinden Geçen Akım Verilerinin Analitikve Yapay Sinir Ağları Modelleri

ÖZ: Bu çalışmada Ogee tipi bağlamalar üzerinden geçen debilerin analitik ve yapay sinir ağları model sonuçları karşılaştırılmıştır. Bunun için $7.5 \mathrm{~cm}$ genişliğinde, $15 \mathrm{~cm}$ yüksekliğinde ve $5 \mathrm{~m}$ uzunluğunda bir açık kanal düzeneği kullanılmıştır. Kullanılan düzenekte farklı savak yükleri geçmesi durumunda debiler ölçülmüş ve bu debiler formül kullanılarak da hesaplanmıştır. Ayrıca deneyden elde edilen sonuçlar ile yapay sinir ağları modeli kurularak debiler tahmin edilmiş ve modelin performansı araştırılmıştır. Elde edilen sonuçlara göre yapay sinir ağları modeli oldukça tatmin edici sonuçlar vermiştir.

Anahtar Kelimeler: Akım, Ogee dolusavak, Yapay sinir ağlan

\section{INTRODUCTION}

Spillways are used to hold water at a certain level in reservoir besides to store water for different aims, such as energy, irrigation, flood control, etc. Ogee-shaped spillw ays let excessive water in reservoir pass to downstream. The ideal form of the spillway recommended by The United States Bureau of Reclamation (USBR, 1987) is seen in Fig. 1. 


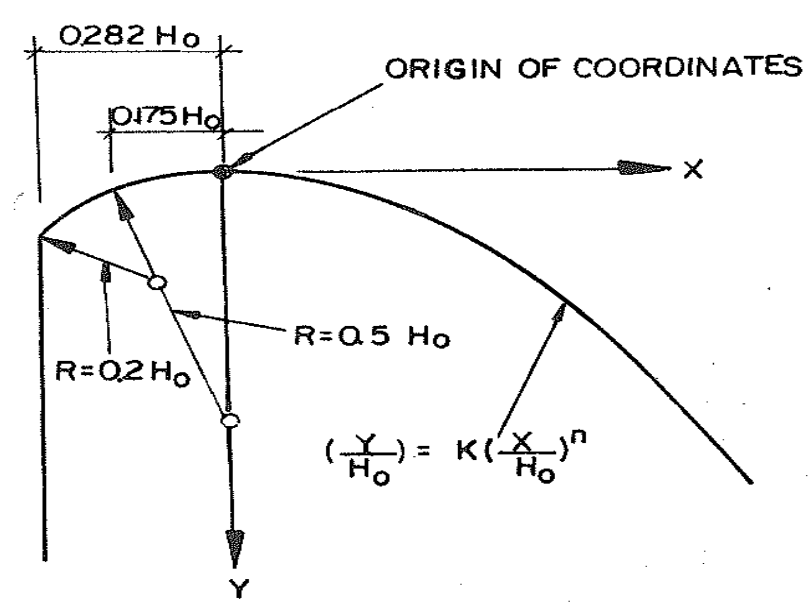

Figure 1. Standard crest profile of an overflow spillway (USBR, 1987)

The downstream of the spillway can be defined by Eq.1.

$$
\frac{Y}{H_{0}}=K\left(\frac{X}{H_{0}}\right)^{n}
$$

$\mathrm{K}$ and $\mathrm{n}$ are constant, depend on the upstream inclination and the velocity and $\mathrm{H}_{0}$ is the design head. The discharge over the spillway can be calculated by Eq.2.

$$
Q=C L H^{3 / 2}
$$

$\mathrm{Q}\left(\mathrm{m}^{3} / \mathrm{s}\right)$ is the discharge, $\mathrm{C}$ is the discharge coefficient, $\mathrm{L}(\mathrm{m})$ is the length of the crest and $\mathrm{H}(\mathrm{m})$ is the head over the crest.

Many researchers have studied for numerical and experimental studies on spillways (Savage and Johnson, 2001; Song and Zhou, 1999; Sanchez et. al., 2000). And ANN model have also used for studies on spillways. Azamathulla et. al. (2008), studied for scour depth prediction for ski-jump type of spillways. They also used some traditional methods. Their study showed that the traditional equationbased methods of predicting design scour downstream of a ski-jump bucked could better be replaced by one of the soft computing schemes. Salmasi and Özger (2014), investigated the applicability and accuracy of the neuro-fuzzy approach in estimating the proper values of en ergy dissipation of skimming flow regime over stepped spillways. They were also developed multi regression equations. They found that neuro-fuzzy model is more successful than regression equations.

In this study, it was aimed that to investigate the capability of ANN model to estimate the discharge value flow over Ogee spillway.

\section{MATERIALS AND METHODS}

In this study, an experimental setup containing a simple flume which was made plexiglass and having $7.5 \mathrm{~cm}$ width, $15 \mathrm{~cm}$ depth and $5 \mathrm{~m}$ length, was used in order to calculate discharge passing over ogee-shaped spillw ay for different heads (Fig. 2). The flume had closed loop water system and the flow to the flume was supplied from constant head water tank and the flow discharge was regulated by a valve. That the transparent flume also enables to see the flow conditions. Flow depth measured with a measurement device holded along the flume to an accuracy of $\pm 1 \mathrm{~mm}$. 


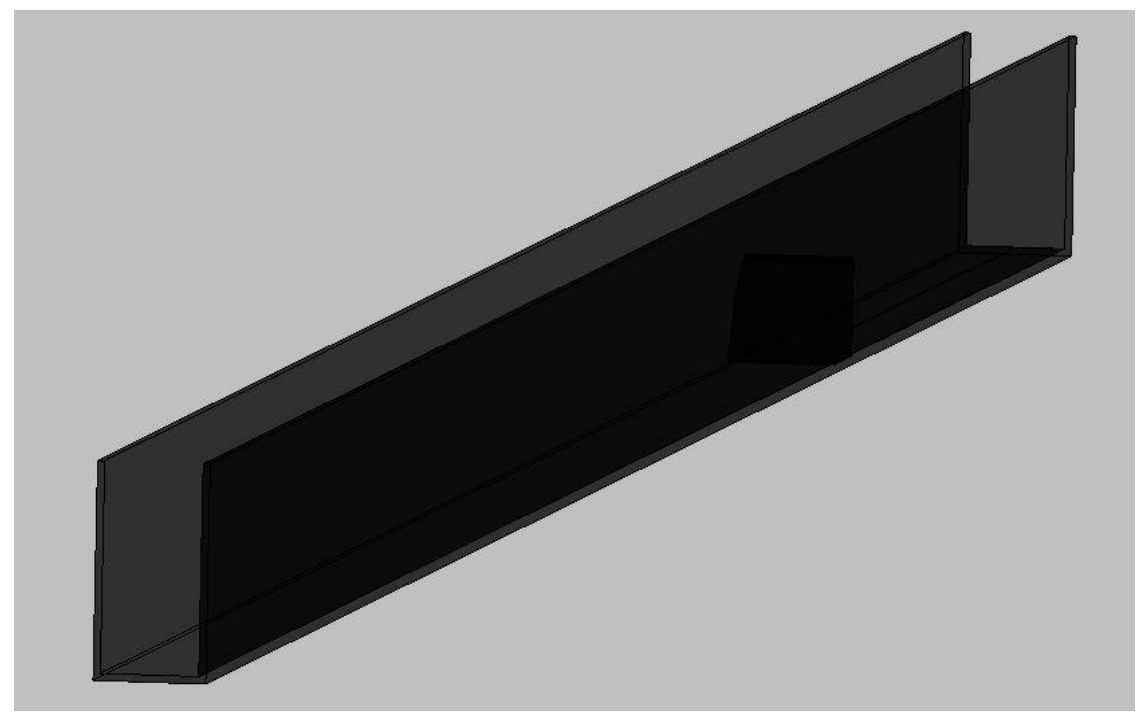

Figure 2. General view of the flume used in the study

A tank, made by smooth plastic which has $63 \times 67 \times 72 \mathrm{~cm}$ dimensions, was used to measure the discharge. An ogee spillway model was modeled by Eq. 1 according to USBR type and manufactured with steel material to use in the experiments (Fig. 3).

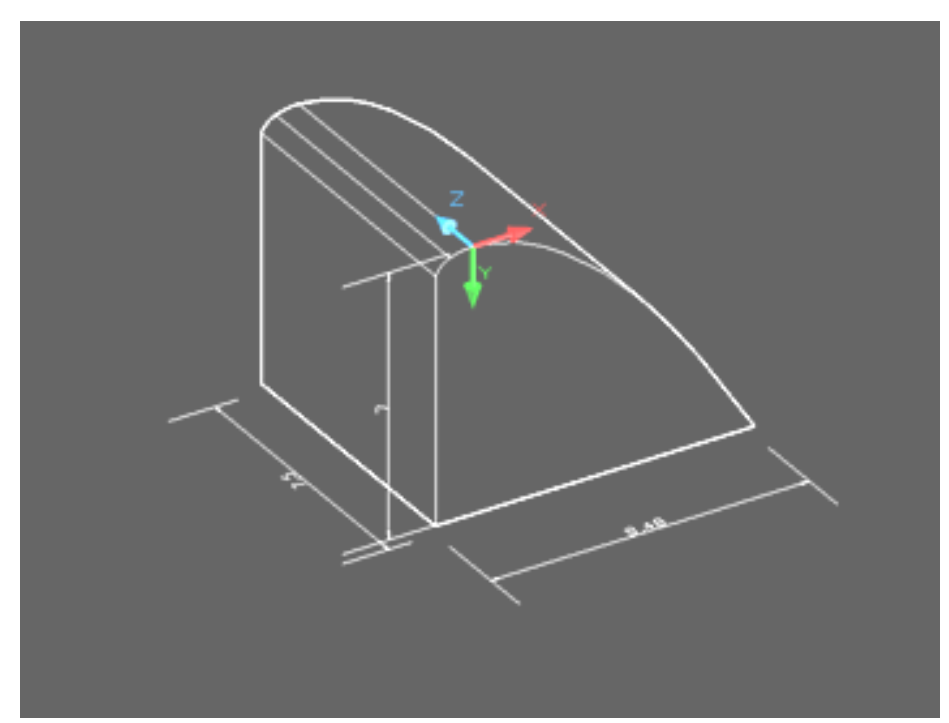

Figure 3. Ogee spillway model

\section{Artificial Neural Networks}

The composition of ANN is inspired from biological neural networks. A neuron is one of the basic components of neural networks. It can vary in terms of size and shape, according to its function and mission in neural systems (Dorum et. al., 2010).

The system consisting of three layers, an input layer, an hidden layer and an output layer, named Multi Layer Perceptron (MLP) (Fig.4). 


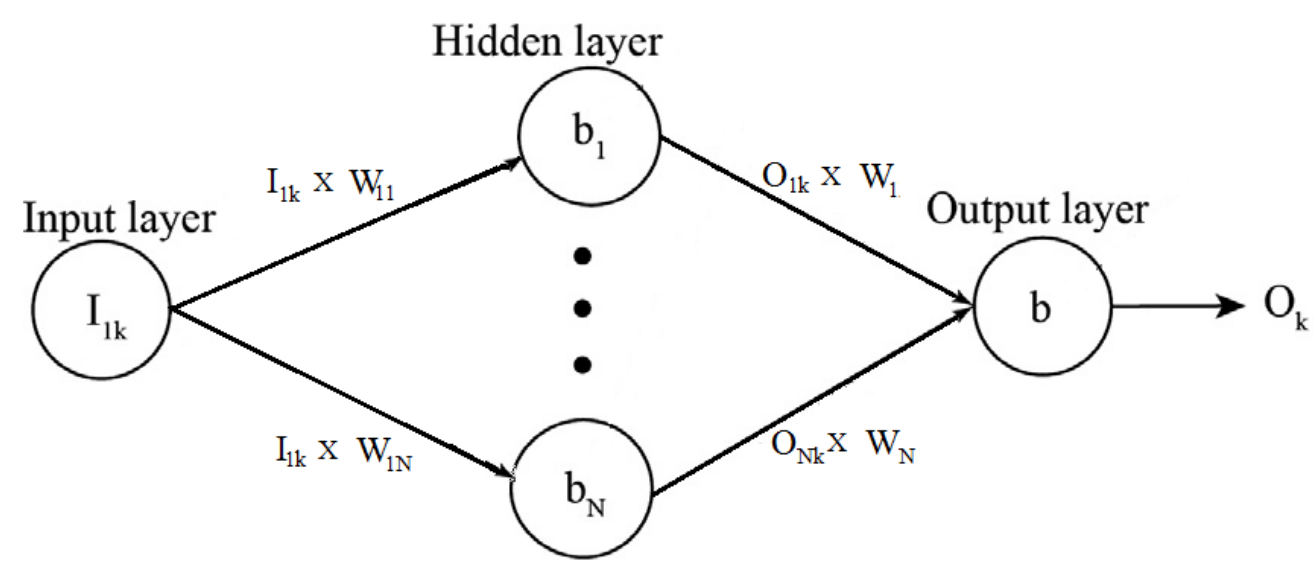

Figure 4. A structure of Multilayer Perceptron

The processing elements in each layer are called neurons or nodes. The input layer contains input parameters. The output layer produces the predictions. The output function of the output layer is a linear function that aggregates the input signals of the output layer. The hidden layers between the input and the output layers deliver signals. The most important part of the hidd en layer having a main role in transferring the network inputs to output is an activation function, typically a continuous and bounded nonlinear function such as hy perbolic-tangent-sigmoid (Tansig) or logarithm-sigmoid (Logsig) functions (Cybenko, 1989).

The mathematical expression of a three-layer feedforward ANN for prediction is

$$
\begin{aligned}
& O_{j k}=f_{1}\left(b_{j}+\sum_{i} W_{i j} I_{i k}\right) \\
& O_{k}=b+\sum_{i} W_{j} O_{j k}
\end{aligned}
$$

where $f_{1}$ is the activation function for the hidden layer, $\mathrm{I}_{\mathrm{ik}}$ is the ith input for the kth sample point, $\mathrm{O}_{j \mathrm{k}}$ is the output of $j$ th node of the hidden layer, $W_{i j}$ and $W_{j}$ are the weights that control the strength of connections between layers and $b_{j}$ and $b$ are the biases that are used to adjust the mean value for the hidden layer and the output layer, respectively (Chitsazan et. al., 2015).

\section{RESULTS AND DISCUSSION}

The flow depths over the spillway were measured for different discharge. The discharges were determined by the tank for each water heads. This process was done with holding time until filling certain volume (Fig. 5). 

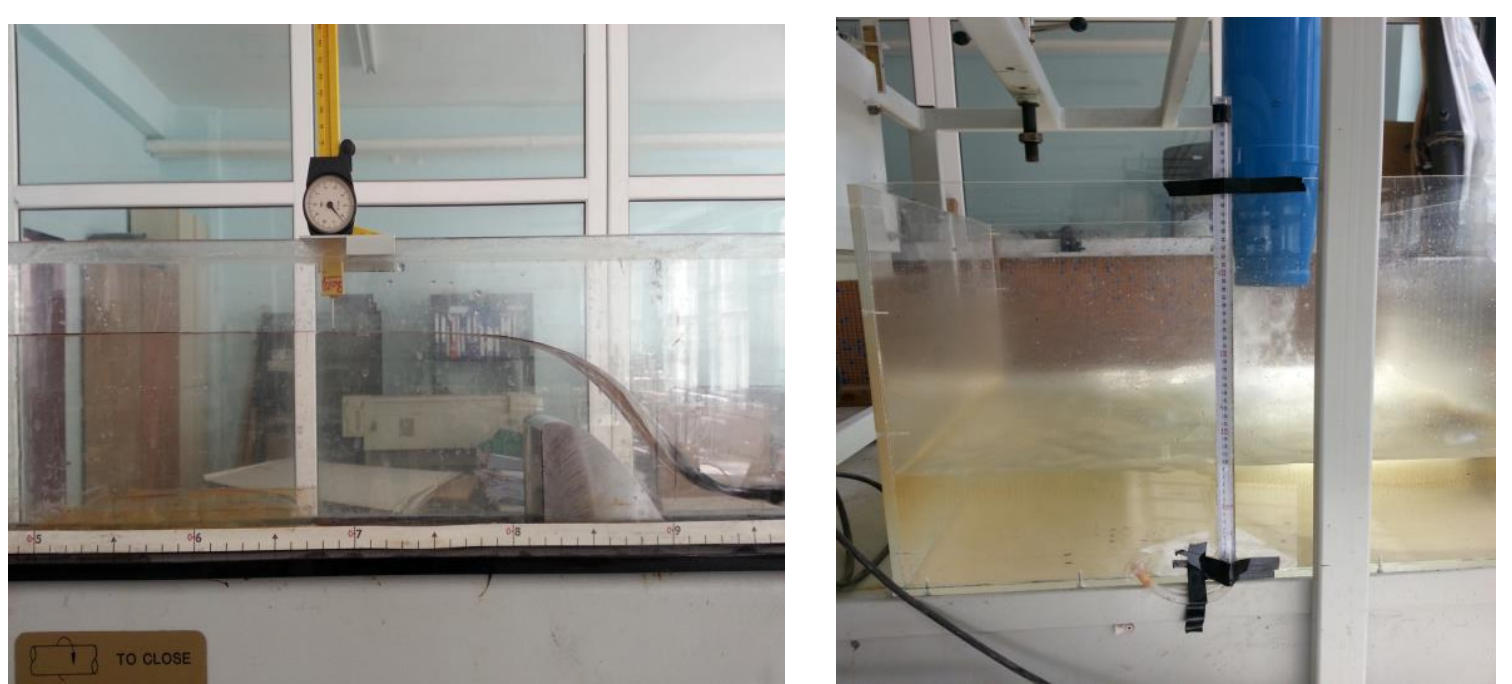

Figure 5. Water depth and discharge measurement points on the experimental set up

Discharge values were also calculated by Eq. 2 using the water heads. Then the discharge values obtained from both experimental and analytical results were compared with each other. Measured water heads and corresponding discharges for both experimental and analytical studies were given in Figure 6 and the relationship betw een them is also given in Figure 7.

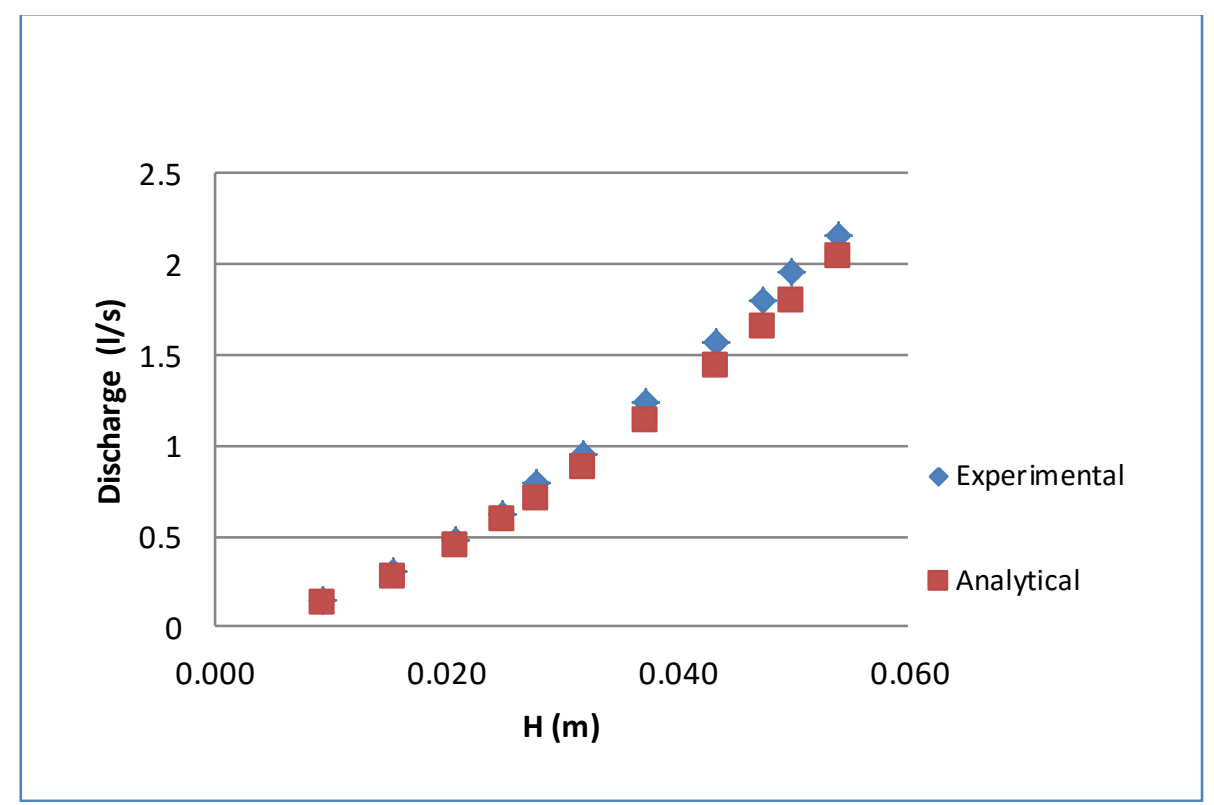

Figure 6. Comparison of the experimental and analytical results 


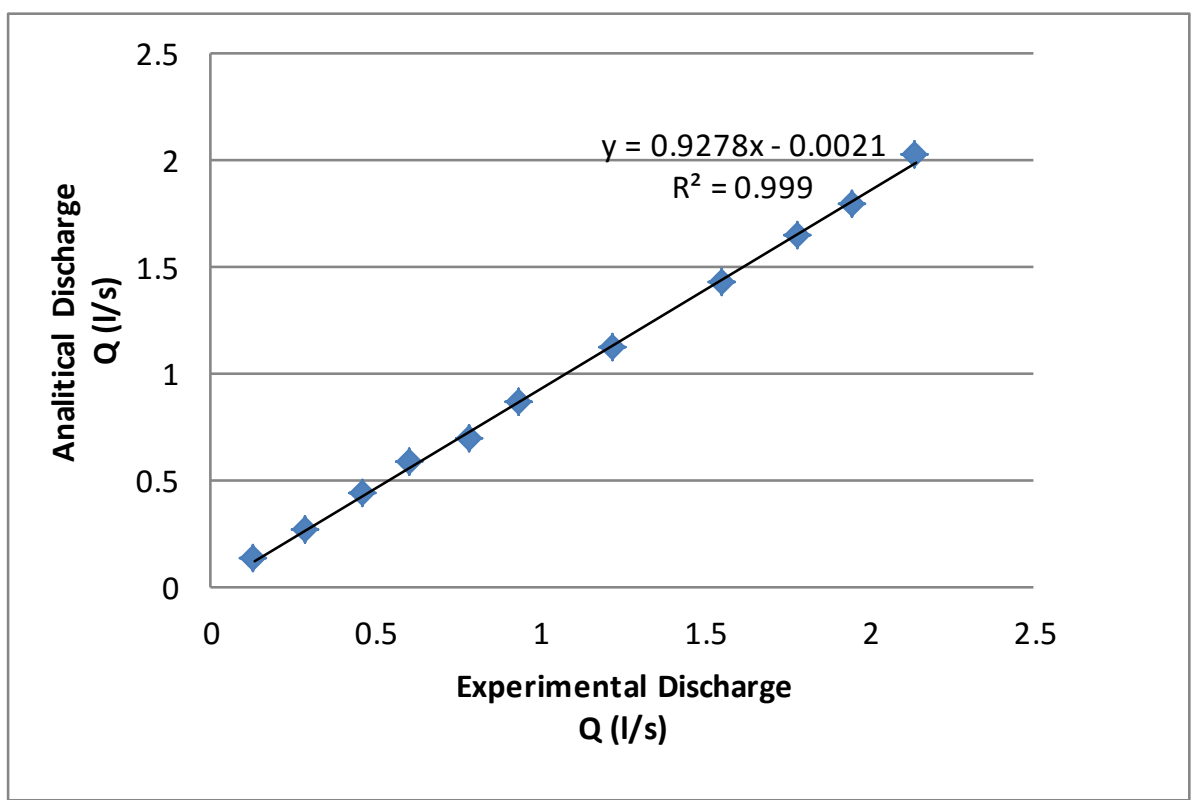

Figure 7. Relationship between the results of experimental and analytical studies

Experimental results were used for ANN modeling. 6 data set of the 11 data set were used for training and remaining 5 data set were used for testing. Feed forward back propagation ANN model and Scaled Conjugate Gradiant (SCG) algorithm were used for modeling. Three layered ANN formed with 1 input layer 1 hidden layer and 1 output layer was used in ANN model. The relationship between ANN results and experimental results is shown in Fig 8.
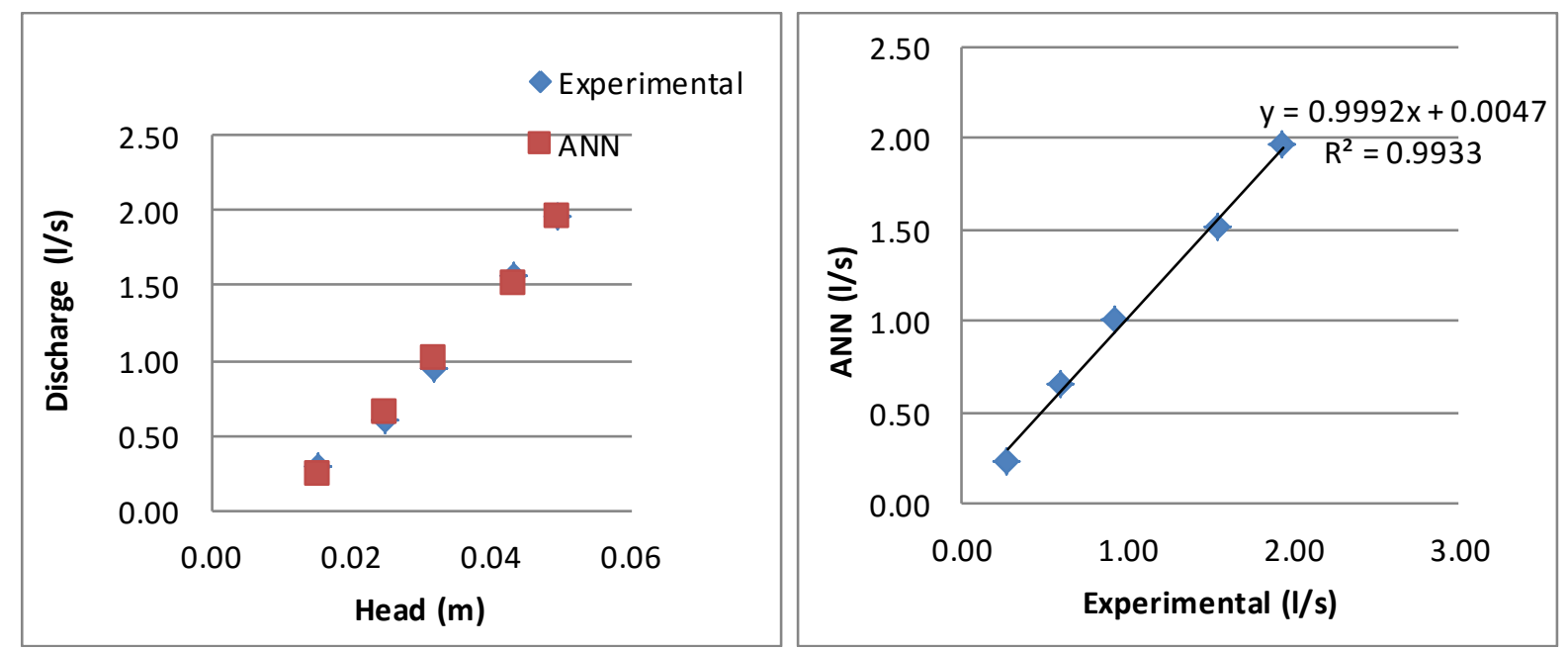

Figure 8. Relationship between the results of experimental and ANN test

\section{CONCLUSIONS}

Hydraulic design of a spillway is one of the most studied subject in hydraulic engineering. Properly designed spillways will be able to pass flood flows efficiently and safely to downstream of dams. So, determining the discharges correctly becomes important for the water structures. In recent years, artificial intelligence methods based on learning from examples statistical methods of artificial neural netw orks have been widely applied in hydraulic structures. In this study, it w as aimed to investigate the ANN performance on determining the discharge over the ogee spillways. For this purpose both experimental and analytical studies were done. It was seen that ANN model produced very successful 
results. Overall, the studies presented in this paper showed us that ANN model can be an alternative method to determine the discharge value passing over the spillways.

\section{REFERENCES}

Azamathulla, H., Md., Deo, M. C., Deolalikar, P. B., 2008, “Alternative Neural Networks to Estimate the Scour Below Spillways", Advances in Engineering Software, Vol. 39, pp. 689-698.

Chitsazan, N., Nadiri, A. A., Tsai, F. T. C., 2015, "Prediction and Structural Uncertainty Analyses of Artificial Neural Networks Using Hierarchical Bayesian Model Averaging", Journal of Hydrology, Vol. 528, pp. 52-62.

Cybenko, G., 1989, "Approximations by Superpositions of A Sigmoidal Function", Mathematics of Control, Signals, and Systems, Vol. 2 (4), pp. 303-314.

Dorum, A., Yarar, A., Sevimli, M. F., Onüçyildiz, M., 2010, “Modelling The Rainfall-Runoff Data of Susurluk Basin", Expert Systems with Applications, Vol. 37 (9), pp. 6587-6593.

Salmasi, F., Özger, M., 2014, "Neuro-Fuzzy Approach for Estimating Energy Dissipation in Skimming Flow over Stepped Spillways", Arabian Journal for Science E Engineering, Vol. 39, pp. 6099-6108.

Sanchez, J. M., Pomares, J., Dolz, J., "Pressure Field in Skimming Flow over A Stepped Spillway", In: Proceedings, International Workshop on Hydraulics of Stepped Spillways, Zurich, Switzerland, 2000.

Savage, B. M., Johnson, M. C., 2001, "Flow over Ogee Spillway: Physical and Numerical Model Case Study", Journal of Hydraulic Engineering, ASCE, Vol. 127(8), pp. 640-649.

Song, C., Zhou, F., 1999, "Simulation of Free Surface Flow over Spillway", Journal of Hydraulic Engineering, ASCE, Vol. 125(9), pp. 959-967.

USBR, 1987, Design of Small Dams, Third Edition, Washington:Water Resources Technical Publication. 